\title{
THE INFLUENCE OF READING HABIT ON STUDENTS’ WRITING SKILL
}

\author{
Endar Rachmawaty Linuwih, Yohanes Kurniawan Winardi \\ (Sastra Inggris Universitas Widya Kartika, Indonesia) \\ (Sastra Inggris, Universitas Widya Kartika, Indonesia) \\ endarrachmawaty@widyakartika.ac.id
}

\begin{abstract}
This research aims to investigate the reading habit quality of EFL learners at Widya Kartika University, Surabaya and to find out the influence of reading habit towards students' writing skill. This is a quantitative ex-post facto study since it examines how the independent variable (reading habit) that has existed affects the dependent variable (writing skill) and the result is in the form of numbers. Sixty two students of Widya Kartika University were selected as the subject of this study. The instruments used in this study were (1) a reading habit questionnaire, to measure the quality of students' reading habit and (2) a writing test, to examine the students' writing skill and how it is influenced by reading habit. The results showed that the students' reading habit quality was fair. Meanwhile, the analysis of Simple Linear Regression concluded that reading habit influences students' writing skill. Moreover, one of the writing components that was mostly influenced by the reading habit was the content.
\end{abstract}

Keywords: Reading, Reading Habit, Writing Skill

\section{INTRODUCTION}

The main objective of learning English is to communicate with others. Reading is one the four main skills that supports communication. In order to communicate in both written and spoken form, the learners need to get a lot of exposure from reading activities in the target language. Linse and Nunan (2005) define reading as a set of abilities including decoding, making sense and also delivering meaning of words from written text. In order to begin reading, learners need to be able to understand of each symbol printed in the written text, decode it as the way they comprehend what they read. Reading can also be defined as interpreting and translating the written form that impacts learner's thought, moral, behavior and judgments (Issa et al, 2012).

Reading skill is not only for learning lessons but also for getting experience, knowledge and everything which can support the learners' study in higher education. Reading is a crucial part in teaching and learning language because it offers good models for writing and gives opportunities for language study. Kartal (2014) also stated that reading is a model of language, reading texts provide opportunities to study language such as; vocabulary, grammar, punctuation and the way to construct sentence, paragraph and text. Therefore, it can be said that reading is an underlying means of supporting the success of learning process (Renandya, 2007). It is in line 
with Adetunji and Oladeji (2007), they maintained reading has a positive influence on academic performance. The opportunities for academic and occupational success are effected by learners' reading skill.

Regarding the significance of reading, it is important that EFL learners establish good English reading habits. According to Issa et al (in Arum, 2018) reading habit is an activity of reading requiring permanent and continuity of practice and becoming a part of someone's life. It is also in line with Acheaw and Larson (2014), they defined that reading habit is an intentional activity arranged consistently in order to gain knowledge related to the academic achievement. According to Gardiner (2005), reading habit could stimulate learners' productivity and creativity. Habit itself means a regular practice doing continuously until it becomes a pattern of behavior (Carter in Elliyina, 2012).

In the accordance with writing skill, students' reading habit plays an important role in writing ability. Many studies found that to learn how to write students need to read, by reading they could increase their vocabulary and their confident in writing as well (Maula, 2005). Reading habit is regarded as the most influenced factor in writing since people usually find out new ideas, fact, information, knowledge and experience from reading activity. Belkhir \& Benyelles (2017) exposed the EFL learners' essay writing difficulties at Tlemcen University. Their study found that one of the difficulties in English writing faced by the learners is due to lack of reading. Learners who have larger receptive vocabulary are likely to know more of those words productively than learners who have smaller receptive vocabulary (Webb, 2008). This shows that those who read more acquire more of the written language.

In addition, reading as a receptive skill is connecting to writing as a productive skill because they have the similar essential goal (Moran and Billen, 2014). Reading textbook triggers the readers to add more knowledge and to develop their critical thinking. It influences the way they organize ideas that helps the learners improve their writing skill. It is in line with Harl (2013), He asserted that reading is acquiring meaning from a text while writing is process when meaning is produced. The ability of writing can be achieved through the habitual activity of reading. In addition the writing skill would improve naturally based on what learners read. 
Moreover, there have been some studies conducted dealing with reading habit and writing skill. Li (2015) in her case study revealed that reading and writing are connected to each other. The reading materials are proven to help the learners to generate ideas and information to their written work. Owushu-Achew (2014) reported that reading habit affects students' academic performance. The students with good reading habit, the academic performance shows good as well. Additionally, Mahyar (2012) exposed the influence of reading habit and the students' writing skill. This previous study revealed that the student with good reading habit shows good as well in their writing production.

Furthermore, Khoirunnisa (2018) stated that academic writing skill has integration with reading because reading is one of the steps of writing process functioned to collect information. In relation to academic writing, for instance: essay, reading is an important activity that should be done by students. They should read many appropriate sources that have similarity with the text they wanted to write. It helps them to construct their ideas based on some references. Crimmon said that before writing a critical essay, we should do some steps such as reading related work. He added that usually understanding text was not easy; sometimes we needed to read in many times (Crimmon, 1975). Based on the explanations of the theories and some former studies, the study intends to investigate the quality of students' reading habit and to find out the influence of reading habit toward writing skill of EFL learners at Widya Kartika University Surabaya.

\section{METHODOLOGY}

The aim of the research is mainly to describe the reading quality of EFL learners at Widya Kartika University in Surabaya and to find out the influence of reading habit on students' writing skill. The researcher used ex-post facto research as the research design. Ary et al. (2010) stated that ex-post facto design is conducted to identify and discover the relationship between two variables without manipulating them because the independent variable has happened in the past. In this case, reading habit included as independent variable so that it could not be manipulated since the reading habit is kind of willingness activity of the readers and could not be done in several times by plans. 
The subject of the research is 62 second-year students of Widya Kartika University taking English course as one of the general basic courses. The instruments which were used in this study were aimed to measure the students' reading habit and writing ability. Students' reading habit was measured through questionnaire and writing test was used to measure writing ability. The writer used the written form in administering reading habit questionnaire adopted form Maula's study in 2015. The questionnaire consists of twenty questions answered by the students using likert scale 1-4 with the following scoring system.

Table 1. Scoring of Questionnaire for Reading Habit

\begin{tabular}{cccccc}
\hline $\begin{array}{c}\text { Positive } \\
\text { Statement }\end{array}$ & Options & Score & $\begin{array}{c}\text { Negative } \\
\text { Statement }\end{array}$ & Options & Score \\
\hline Always & $\mathrm{A}$ & 4 & Always & $\mathrm{A}$ & 1 \\
Often & $\mathrm{B}$ & 3 & Often & $\mathrm{B}$ & 2 \\
Seldom & $\mathrm{C}$ & 2 & Seldom & $\mathrm{C}$ & 3 \\
Never & $\mathrm{D}$ & 1 & Never & $\mathrm{D}$ & 4 \\
\hline
\end{tabular}

Then to know the percentage of students' reading habit, Arikunto (2006) suggested these five categories.

\begin{tabular}{l|c}
\multicolumn{2}{|c}{ Table 2. Category of reading habit } \\
\hline very good & $81-100 \%$ \\
Good & $61-80 \%$ \\
Fair & $41-60 \%$ \\
Bad & $21-40 \%$ \\
Very bad & $0-20 \%$
\end{tabular}

In addition, Writing test used is the timed writing task required the subjects to write an essay based on the given topics. The subjects were free to create their own contexts that were relevant to the topic. The topics were taken from ETS (Educational Testing Service) computerbased writing topics which could also be found in http://www.ets.org. Within 30 minutes, the subjects were free to plan, write $300-350$ words, and revise their writing. They should choose one topic out of four topics available. The subject writing quality is measured using the analytical scoring system by Jacob et al' (1981) which assesses the five components in students' writing namely; content, organization, vocabulary, language use, and mechanics. Therefore, the scores are classified into the criteria ability that can be seen as follows: 
Table 3. Criteria of Ability

\begin{tabular}{|cc|}
\hline Score & Criteria of Ability \\
$91-100$ & Excellent \\
$81-90$ & Very good \\
$71-80$ & Good \\
$61-70$ & Average \\
$51-60$ & Fair \\
$41-50$ & Poor \\
Less than 40 & Inadequate \\
\hline
\end{tabular}

The collected data then tabulated and analyzed by SPSS (Statistical Package for the Social Sciences) version 17 using Simple Linear Regression formula to see the influence of independent variable toward dependent variable (Trihendradi, 2009)

\section{FINDINGS AND DISCUSSION}

\section{The Quality of Students' Reading Habit}

The result of students' reading habit quality is based on the questionnaire consisting of 20 questions about reading habit. It can be seen in the chart below.

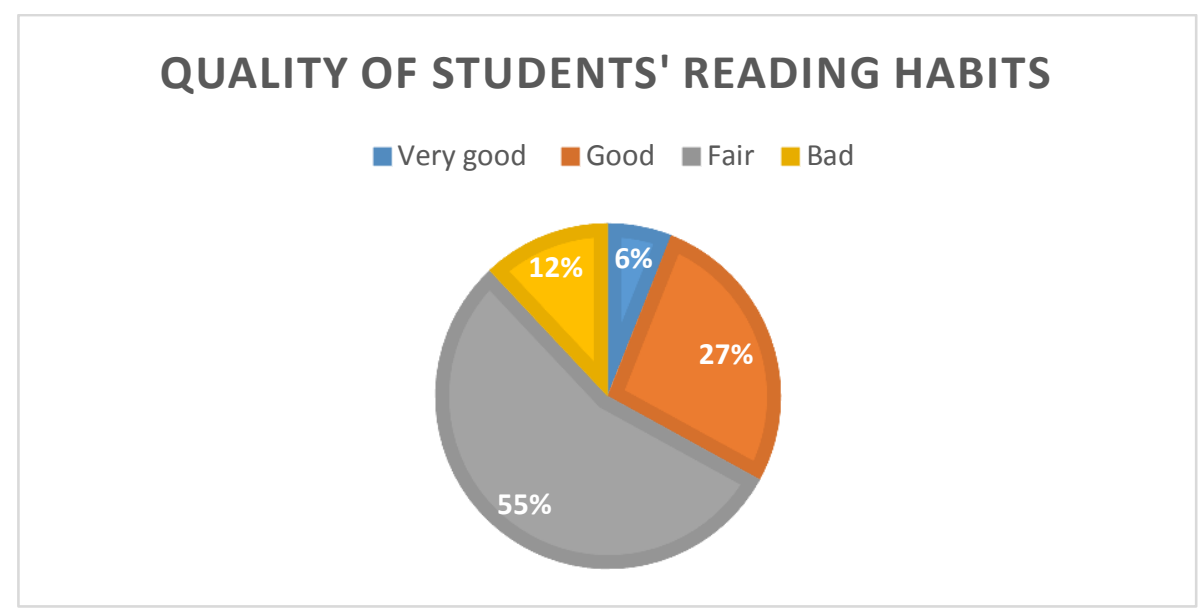

Figure 1. Quality of Students' Reading Habit

There are 17 students who have good reading level or as many as $27 \%$ of the total students. Then, there are 34 students who have fair reading level or as many as $55 \%$ of the total students. In addition, there are seven students who have very bad reading level as many as $12 \%$. 
Last, there were are four students who have very good reading level or as many as $6 \%$ of the total students. The researcher concludes that the quality of students' reading habit in on fair level. According to the result shown above, it revealed that the second year students of Widya Kartika University has dominant students with fair reading quality. However, students with poor reading quality were also existing in amount of numbers.

According to the questionnaire, the students stating that they often read English books are only those with very good reading quality. The others mention that they sometimes even rarely spend time reading English books. In term of the reading frequency, some of the students have high frequency in reading. Frequency is the essential aspect of reading. It has been proven to improve students' vocabulary, knowledge, and critical thinking. Every day, the students (25\%) always spend 15-30 minutes reading. Most of the students (40\%) sometimes spend 15-30 minutes reading. However, there are still a few students (35) read less than 15 minutes.

Moreover, the students read a lot of kinds of reading sources, such as book, newspaper, magazine, website, etc. most of the students (62\%) mention that every day, they sometime read a book, newspaper, magazine, website, etc. Related to the reasons for reading. Only a few students think that reading is always fun as reading is considered to be the pleasure of entertain. The great number of students (75\%) choose reading sometimes is no more than finding particular information form the task given. Students' activity is always connected to read, they are demanded to read as much as possible. There is a question related to students' reading activity before class, the students with very bad reading habit quality admit that they never read the materials given in the text book before class. On the other hand, the students with good reading habit quality realize how important the reading is, so they often read the materials before class.

In accordance with improving vocabulary and knowledge, most of the students (55\%) are often curious with the meaning of some new words found in the text. They try to look the difficult words up in the dictionary not only to get the meaning but also its pronunciation. Finally, in term of extensive reading, some students (24\%) state that they often spend their reading in their leisure time, they believe in reading for pleasure. Most of the students (45\%) sometimes read in their free time but there are still a few students (3\%) who admit that they never read during their leisure time. 


\section{The Effect of Reading Habit on Students' Writing Skill.}

In order to reveal the influence of students' reading habit on writing skill, the writing test was administered. The result of students' writing test is used to find out whether it is influenced by students' reading habit. The criteria of students' writing test result can be seen in the figure 2 ;

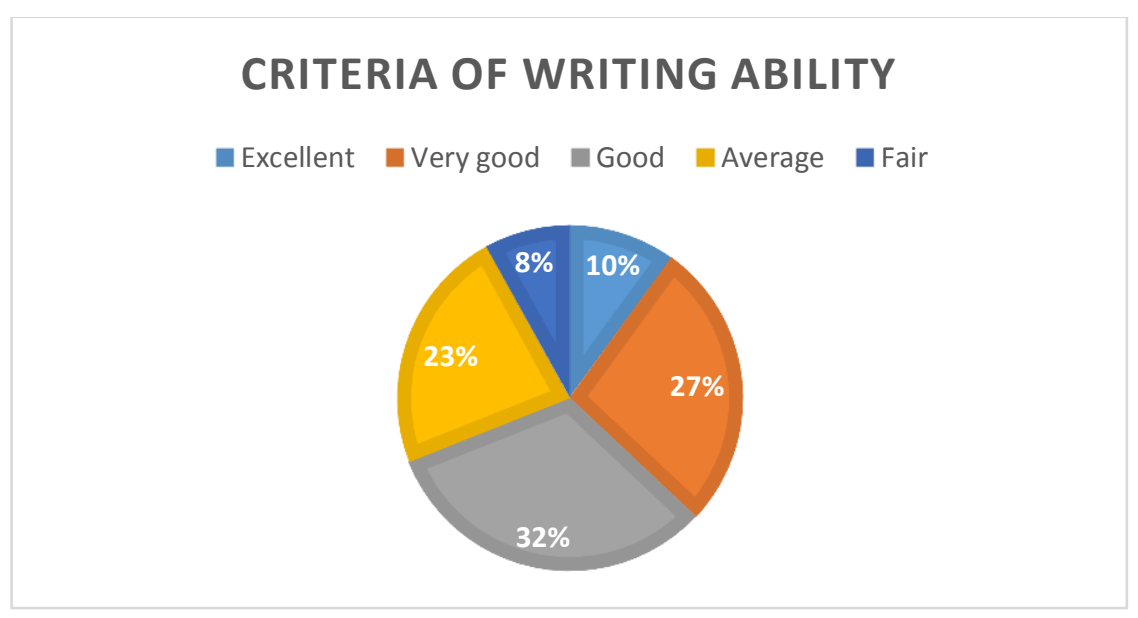

Figure .2. Students' Criteria of Writing Ability

From the chart above, it can be concluded that the second year students of Widya Kartika University has dominant students with good writing quality. The mean score of students with good writing quality is 72 . Those who have excellent writing quality get 93 as the highest score. However, there are five students (8\%) who have fair writing quality with the score range from 51 - 60. There are five components (content, organization, vocabulary, language use, and mechanics) measured in students' written work.

From the results of reading habit quality and writing skill, it is possible to do a further analysis using Simple Linear Regression to find out the influence of students' reading habit on writing skill. The result of calculation using SPSS shows that there is a positive and significant influence of reading habit towards students' writing skill with significant value 0.001 (value of Sig < 0.05). It can be concluded that the higher the quality of reading habit, the more influenced it will be toward students' writing skill. In addition, the value of R Square is 0.823 . This shows that the influence of independent variable (reading habit) on the dependent variable (writing skill) is equal to $82.3 \%$ and the rest is influenced by other factors which are not investigated in this study. 
Since the result of the study showed that there is a positive and significant effect of reading habit on writing skill, it is in line with Harl (2013) stating that writing is influenced by reading because reading determines the quality of writing. The students who read constantly will be able to write well because the understand how to write. During the writing process, the students easily recall their memory in term of words or vocabulary, grammar in use, and also the comprehension they have read. It is also proven by the data of this study showing that when score of habit is bad, their writing quality is also bad. For example there is one student who gets 40 for the quality of reading habit, and the score in writing test is 58. It means that if the students' reading habit is bad, their writing test score is also bad. In contrast, if the score of students' reading habit is good, their writing test score is also good. As the result showed that there is a significant influence of reading habit towards writing skill, the researcher would like to know more writing aspect is influenced the most by reading habit. The chart below illustrate the mean of writing components.

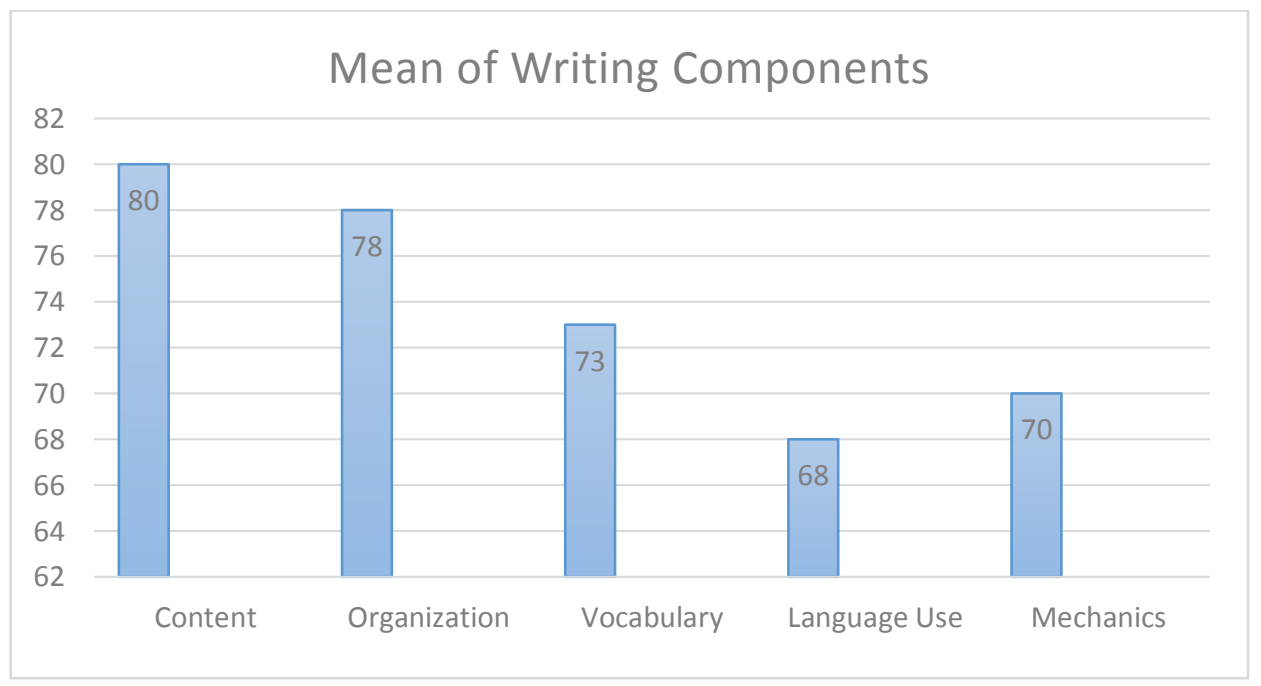

Figure 3. Mean of Writing Components

The chart shows that the writing component which is highly achieved is the content. It reveals that most of the students know the subject very well and they are able to put the substantive content which is relevant to assigned topic. On the other hand, another component which is hard to achieve is language use, this is dealing with the use of grammar and sentence 
construction. Therefore, according to the chart, among those writing components (content, organization, vocabulary, language use, and mechanic), the highest mean is the content. This implies that content is the most influential component from reading habit to writing skill.

It also supports the theory by Tierney and Leys (in Arum, 2018) stating that writing is influenced reading because several parts of reading comprehension play important roles in writing process. Those parts are the writer's style, the conveyed idea, the additional materials, and the reading acquirement itself. It was proven by the finding of this study showing that content is the most influential component from reading to writing. This mean students have a process to bring their understanding from reading material, figure out the ideas in reading acquisition and compose it into good writing.

\section{CONCLUSION}

This study aims to examine the quality of students' reading habit and to find out whether the reading habit influences the writing skill. To obtain the data, a questionnaire of reading habit and writing test are administered. From the result of questionnaire, there are 17 students who have good reading level or as many as $27 \%$ of the total students. Then, there are 34 students who have fair reading level or as many as $55 \%$ of the total students. In addition, there are seven students who have very bad reading level as many as $12 \%$. Last, there were are four students who have very good reading level or as many as $6 \%$ of the total students. It is concluded that the students dominantly have a fair level of reading habit.

Moreover, the analysis of Simple Linear Regression using SPPS showed that there is a significant influence of students' reading habit toward writing skill. It can be seen form the significant value is 0.001 which is lower than 0.05 with the value of $\mathrm{R}$ Square is 0.823 . Therefore, it can be interpreted that reading habit significantly influences writing skill and the influence of reading habit on writing skill is equal to $82.3 \%$ and the rest is influenced by other factors which are not examined in this study. Additionally, the content is the writing component that is most influenced by reading habit. 


\section{REFERENCES}

Acheaw, M. \& Larson, A. (2014). Reading habit among students and its effect on academic performance: A study of students of Koforidua Polytechnic. Library Philosophy and Practice.

Adetunji, A. \& Oladeji, B.O. (2007). Comparative Study of the Reading Habit of Boarding and Day Secondary School Students in Osogbo, Osun State, Nigeria. Pakistan Journal of Social Science, 4(4): 509-512.

Arum, D. (2018). The Effect of Reading Habit on Students' Writing Performance. RETAIN Journal 6(2): 11-18

Gardiner, S. (2005). Building Student Literacy Through: sustained Silent Reading. USA: Association for Supervision and Curriculum Development.

Harl, A. (2013). A Historical and Theoretical Review of the Literature: Reading and Writing Connections. In: A Horning and E. Kraemer, ed. Reconnecting Reading and Writing. United Stated of America: Parlor Press LLC and The WAC Clearinghouse.

Hyland, K. (2003). Second Language Writing. New York: Cambridge University Press.

Issa, A., et al. (2012). Reading interests and habits of the Federal Polytechnic, OFFA, students. International Journal of Learning and Development, 2(1).

Khoirunnisa, and Safitri, I. (2018). Reading Habit and Its Effect on Academic Writing Skill: A Study of Master Degree Program. JELE (Journal of English Language and Education), 4(1): $43-50$

Krashen, S. (2004). The Power of Reading. Westport, Conn.: Libraries Unlimited

Linse, C. and Nunan, D. (2005). Practical English Language Teaching. New York: McGrawHill Companies.

Li, Z. (2015). Connecting Reading and Writing: A Case Study. English Language Teaching, $8(6)$.

Maula, I. (2015). The Correlation between Students' Reading Habit and Their Ability on Writing Narrative Text. Thesis of Semarang State University.

Meyers, A. (2005). Gateways to Academic Writing: Effective Sentences Paragraph and Essay. New York: Longman.

Moran, R. \& Billen, M. (2014). The reading and writing connection: Merging two reciprocal content areas. Georgia Educational Researcher, 11(1). 
Renandya, W.A. (2007). The Power of Extensive Reading. RELC Journal, 38(2): 133-149. (Online), (http://rel.sagepub.com/cgi/content/abstract/38/2/1 33), retrieved on 04 January, 2020 .

Trihendradi, C. (2009). Melakukan Analisis Statistik Menggunkan SPSS 17. Yogyakarta: C.V. Andi Offset 